\title{
PERANCANGAN APLIKASI PENJUALAN HEWAN TERNAK UNTUK QURBAN DAN AQIQAH DENGAN METODE UNIFIED MODELING LANGUAGE (UML)
}

\author{
Roys Pakaya ${ }^{1)}$, Abdul Rahman Tapate ${ }^{2)}$, Salman Suleman ${ }^{3)}$ \\ ${ }^{1,2,3}$ Program Studi Teknik Informatika, Politeknik Gorontalo \\ Email : royspakaya@poligon.ac.id ${ }^{1)}$
}

\begin{abstract}
ABSTRAK
Qurban adalah proses ritual dalam hukum Islam untuk pengorbanan hewan ternak selama Idul Adha. Dalam hukum Islam, Aqiqah terdiri dari pengorbanan satu (untuk anak perempuan) atau dua (untuk anak lakilaki) hewan dan daging Aqiqah didistribusikan kepada orang miskin dan anak yatim. Sebagian besar petani kesulitan menjual hewan untuk Qurban dan Aqiqah. Sebaliknya, banyak komunitas Muslimah sebagai pembeli merasa kesulitan untuk mendapatkan informasi tentang hewan kurban yang dapat digunakan untuk Qurban dan Aqiqah , dengan harga yang wajar, kualitas dan juga jaminan halal.

Teknologi sering dijadikan solusi atas permasalahan yang terjadi. Pada penelitian ini, teknologi yang diterapkan adalah dengan membuat aplikasi penjualan hewan ternak berbasis web dan android. Ini dimaksudkan agar para konsumen dan penjual akan terhubung dengan sebuah system yang terintegrasi. Sehingga memudahakan keduanya melakakukan proses jual dan beli.

Tujuan dari penelitian ini adalah untuk merancang aplikasi yang dapat membantu konsumen dan penjual hewan Qurban dan Aqiqah dalam melakukan proses transaksi jual beli dengan mudah. Unified Modeling Language (UML) adalah metode yang dipilih oleh peneliti untuk perancangan system pada penelitian ini. Dari hasil diksusi, evaluasi dan impelementasi uji aplikasi ini dapat membantu penjual dalam memberikan informasi kepada konsumen yang membutuhkan hewan Qurban dan Aqiqah sehingga memudahkan proses transaksi jual beli dan meningkatkan pendapatan penjual ternak
\end{abstract}

Kata Kunci: Perancangan, Penjualan, Aqiqah, UML

\section{ABSTRACT}

Qurban is a ritual process in Islamic law for the sacrifice of livestock during Eid al-Adha. In Islamic law, Aqiqah consists of sacrifice of one (for girls) or two (for boys) animals and Aqiqah meat distributed to the poor and orphans. Most farmers find it difficult to sell animals for Qurban and Aqiqah. On the contrary, many Muslimah communities as buyers find it difficult to obtain information about sacrificial animals that can be used for Qurban and Aqiqah, with reasonable prices, quality and also halal guarantees.

Technology is often used as a solution to problems that occur. In this research, the technology applied is to create a web-based and android-based livestock sales application. This is intended so that consumers and sellers will be connected to an integrated system. So as to facilitate both the process of selling and buying.

The purpose of this study is to design applications that can help consumers and sellers of Qurban and Aqiqah animals in the process of buying and selling transactions easily. Unified Modeling Language (UML) is the method chosen by researchers for system design in this study. This application can help sellers in providing information to consumers who need Qurban and Aqiqah animals so as to facilitate the process of buying and selling and increasing livestock seller income

Keywords: Design, Sales, Aqiqah, UML

\section{PENDAHULUAN}

Peternakan merupakan salah satu cabang dari jenis pertanian yang ada, peternakan itu sendiri adalah suatu jenis usaha yang berkosentrasi dalam membudidayakan hewan ternak (Wati, 2012). Hewan ternak di manfaatkan sebagai salah satu media untuk mendapatkan penghasilan. Banyak masyarakat yang membudidayakan hewan ternak untuk dijual terutama untuk jenis hewan yang akan dipapakai pada saat ibadah Qurban dan Aqiqah.
Hewan Qurban adalah sembelihan seperti: Unta, sapi atau kambing pada hari idhul Adha dan pada hari-hari tasyrik $(11,12,13$ Zulhijjah) dalam rangka ibadah dan bertaqarrub kepada Allah Subhanahu Wata'ala. Sedangkan Aqiqah secara lughawi adalah rambut yang berada pada kepala bayi, yang sebagian pandangan menganggap najis yang perlu di bersihkan pada masa umur tujuh hari, ada yang berpendapat sembilan bahkan sebelas hari. 
Peternak yang menjual hewan ternak di Provinsi Gorontalo, khususnya Kota Gorontalo, masih menjadi sumber pendapatan utama untuk memenuhi kebutuhan hidup keluarga. Ini dibuktikan dengan adanya proses jual beli yang sering terjadi pada peternakan tersebut. Peternak melakukan proses penjualan pada ternak mereka dengan cara membawa ternak di pasar serta melalui media promosi dari teman ke teman.

Berdasarkan hasil observasi yang dilakukan kepada para pemilik hewan (peternak) sering mengalami permasalahan penjualan hewan-hewan khusus seperti hewan Qurban dan Aqiqah. Permasalahan yang terjadi adalah kendala saat melakukan penjualan hewan Qurban dan kepada calon pembeli sebagai konsumen yang akan membeli hewan tersebut. Kendala dan keterbatasan informasi tentang hewan-hewan yang Halal dan dapat dijadikan untuk hewan Qurban dan Aqiqah menurut syariat agama Islam. Kendala lainnya dalam penjualan hewan ternak adalah mendapatkan informasi tentang kualitas dan harga yang sesuai. Permasalahan diatas merupakan kendala bagi kedua pihak (penjual dan pembeli), terutama kepada masyarakat sebagai pembeli yang membutuhkan hewan untuk kegiatan Qurban dan Aqiqah .

Pemanfaatan teknologi menjadi solusi permasalahan seperti pada kasus diatas. Teknologi yang diusulkan dan diterapkan adalah membuat aplikasi informasi penjualan hewan ternak untuk Qurban dan Aqiqah berbasis web dan android. Tujuan dari aplikasi yang dimaksudkan agar para konsumen dan penjual ternak akan melakukan transaksi jual-beli yang terhubung dengan sebuah sistem. Sistem tersebut dilengkapi pemilihan metode pembayaran tunai atau non-tunai (transfer) yang disesuaikan dengan keinginan dari para pembeli. Sehingga pada saat transaksi pembayaran antara pembeli dan penjual akan lebih mudah.

Adapun yang menjadi rumusan masalah dalam penelitian ini, yaitu:

1. Bagaimana konsumen bisa mendapatkan informasi penjualan hewan ternak untuk aqiqah dan qurban?

2. Bagaimana penjual hewan aqiqah dan qurban dalam meningkatkan pendapatannya ?

Berdasarkan rumusan masalah yang ada maka tujuan penelitian ini adalah sebagai berikut :

1. Membantu konsumen dalam melakukan pembelian hewan qurban dan aqiqah

2. Meningkatkan pendapatan penjual hewan aqiqah dan qurban

\section{LANDASAN TEORI}

\subsection{Penelitian Terdahulu}

Penelitian tentang aplikasi jual beli hewan Qurban dan Aqiqah sebenarnya sudah ada pernah dilakukan oleh peneliti lainnya. Misalnya, penelitian yang dilakukan (Wati, 2012) yang berjudul tentang
Sistem Informasi Qurban online berbasis web pada toko hewan Qurban H. Sofi. Perancangan sistem jual-beli hewan Qurban menerapkan aplikasi menggunakan situs web yang dilengkapi dengan pengolahan data yang terdapat ditoko tersebut. Serta penelitian yang pernah dilakukan oleh (Oktaviani \& Suryadi, 2017) yaitu Sistem informasi penjualan kambing dan pemesanan hewan Aqiqah berbasis $e$ commerce pada UKM Hasanah. Sebuah sistem informasi berbasis e-commerce, dimana sistem informasi tersebut dapat digunakan oleh pihak konsumen dan produsen. Sistem informasi tersebut telah dilakukan pengujian dengan metode black box dimana hasilnya adalah sebuah menu dapat digunakan sesuai dengan fungsi dan tujuannya.

Adapun perbedaan penelitian tentang penjualan hewan Qurban dan Aqiqah yang telah dilakukan sebelumnya dengan penelitian ini adalah penelitian yang telah dilakukan sebelumnya semua aplikasi yang dibuat berbasis web dan aplikasi berbasis android yang masing-masing berdiri sendiri, Sedangkan aplikasi yang penulis buat yaitu dengan menggabungkan Aplikasi berbasis web dan berbasis android sehingga lebih memudahkan penjual dan konsumen dalam menggunakan aplikasi ini.

\subsection{Kajian Teori}

\subsubsection{Perancangan Sistem}

Dalam pembuatan suatu aplikasi, tentunya yang pertama dilakukan yaitu mendesain system baru yang dapat menyelesaikan masalah - masalah yang dihadapi perusahaan yang diperoleh dari pemilihan alternatif system yang terbaik (Kenneth, 2013).

Metode Unified Modeling Language (UML) dipilih dalam menyelesaikan masalah perancangan sistem pada aplikasi yang akan dibangun. Adapun yang menjadi kelebihan metode UML, yaitu: memberikan visualisasi permodelan kepada user dari berbagai bahasa pemrograman, memodelkan sistem yang berkonsep berorientasi objek (PBO), menciptakan suatu bahasa permodelan yang nantinya dapat digunakan oleh manusia maupun mesin. Sehingga akan memudahkan dalam menganalisa dan membuat aplikasi penjualan hewan ternak untuk qurban dan aqiqah.

Perancangan system adalah merancang suatu system yang baik yang berisi langkah-langkah operasi pengolahan data dan proses prosedurprosedur untuk mendukung operasi system. Tujuan dari perancangan system adalah untuk memenuhi kebutuhan para pemakai system serta memberikan gambaran yang jelas dan rancang bangun yang lengkap kepada programmer dan ahli-ahli yang terlibat didalam. 


\subsubsection{Unified Modeling Language (UML)}

Unified Modeling Language (UML) merupakan kesatuan struktur dan cara bagi pemodelan desain program berorientasi objek $(O O P)$ serta aplikasinya. $U M L$ adalah metodologi untuk mengembangkan sistem $O O P$ dan sekelompok perangkat tool untuk mendukung pengembangan sistem tersebut. UML mulai diperkenalkan oleh Object Management Group, sebuah organisasi yang telah mengembangkan model, teknologi, dan standar OOP sejak tahun 1980-an. Sekarang UML sudah mulai banyak digunakan oleh para praktisi $O O P$. $U M L$ merupakan dasar bagi perangkat (tool) desain berorientasi objek dari IBM. UML adalah suatu bahasa yang digunakan untuk menentukan, memvisualisasikan, membangun, dan mendokumentasikan suatu sistem informasi. $U M L$ dikembangkan sebagai suatu alat untuk analisis dan desain berorientasi objek oleh Grady Booch, Jim Rumbaugh, dan Ivar Jacobson. Namun demikian $U M L$ dapat digunakan untuk memahami dan mendokumentasikan setiap sistem informasi. Penggunaan $U M L$ dalam industri terus meningkat. Ini merupakan standar terbuka yang menjadikannya sebagai bahasa pemodelan yang umum dalam industri peranti lunak dan pengembangan sistem.

\subsubsection{Qurban dan Aqiqah}

Dalam Kamus Besar Bahasa Indonesia (2012), "Qurban adalah persembahan kepada Allah (seperti biri-biri, sapi, unta yang disembelih pada hari lebaran Haji) sebagai wujud ketaatan muslim kepada-Nya". Selanjutnya pengertian Qurban secara etimologi dan terminologi yaitu hewan yang khusus disembelih pada saat hari raya kurban ('Id al-adha) dan hari tasyriq (hari tanggal 10, 11, dan 13 bulan Dzul Hijjah) beserta malamnya, sebagai upaya mendekatkan diri kepada Allah SWT (Abdullah, 2016). Jadi, yang dimaksud dengan Qurban ialah suatu bentuk ibadah yang disyariatkan Allah dengan cara menyembelih hewan dengan syarat dan cara yang sesuai dengan syariat Islam dan pada waktu yang telah ditetapkan yakni hari tasyriq.

Sedangkan Aqiqah berasal dari kata 'Aqqa yang berarti mencukur. Atau menyembelihkan kambing. Makna lainnya Aqiqah adalah rambut yang ada di kepala bayi yang baru lahir. Menurut alAzhariy dalam "al-Tahdzib" yang mengutip pernyataan Abu 'Ubaid, bahwa 'Aqiqah pada mulanya berarti "rambut yang ada pada kepala seorang bayi ketika ia dilahirkan." Aqiqah juga berarti "kambing yang disembelih untuk anak yang baru dilahirkan (Al-Kusyairi, 2015). Jadi yang dimaksud dengan Aqiqah adalah ibadah yang disyariatkan Allah kepada kedua orang tua atas bayi yang baru dilahirkan berupa penyembelihan kambing.

Dalam konteks penelitian ini, hewan Qurban dan hewan Aqiqah adalah hewan-hewan yang dijual oleh para peternak yang dikhususkan untuk ibadah Qurban dan ibadah Aqiqah.

\section{METODOLOGI PENELITIAN}

\subsection{Analisis Data}

Analisis data merupakan cara untuk mengolah data menjadi sebuah informasi agar data tersebut mudah dipahami dan dapat bermanfaat untuk solusi sebuah permasalahan. Analisis data juga dapat diartikan menjadi kegiatan yang dilakukan untuk untuk merubah data hasil dari penelitian menjadi informasi yang nantinya dapat dipergunakan untuk mengambil kesimpulan.

Untuk mendapatkan data terbaru dan akurat, penelitian ini menggunakan metode observasi dan wawancara pada 98 responden yang berada di Kota Gorontalo. Responden dari unsur penjual berjumlah 31 orang dan responden dari unsur pembeli berjumlah 67 orang.

\subsection{Analisis Sistem}

Analisis system dapat didefinisikan sebagai penguraian dari suatu system yang utuh ke dalam bagian-bagian komponennya dengan maksud untuk mengidentifikasi dan mengevaluasi permasalahan, kesempatan, hambatan yang terjadi dan kebutuhan yang diharapkan sehingga dapat diusulkan perbaikkan-perbaikkan. Analisis system dapat juga diartikan sebagai penelitian atas system yang telah ada dengan tujuan untuk merancang system yang baru atau diperbaiki. Dalam proses pembuatan suatu system mutlak dilakukan penelitian dan penganalisaan tentang system yang akan dibangun (Ladjamudin, 2005).

Analisis system pada penelitian ini menggunakan model System Development Life Cycle (SDLC) atau Sekuensial Linier sering disebut juga Model Air Terjun. Model ini mengusulkan sebuah pendekatan perkembangan perangkat lunak yang sistematik dan sekunsial yang dimulai pada tingkat dan kemajuan sistem pada seluruh analisis, desain, kode, pengujian, dan pemeliharaan

Model ini disusun bertingkat, setiap tahap dalam model ini dilakukan berurutan, satu sebelum yang lainnya. Model ini biasanya digunakan untuk membuat sebuah software dalam skala besar dan yang akan dipakai dalam waktu yang lama..

Tahapan-tahapan model SDLC:

1. Fase Perencanaan Sistem

2. Fase Analisis Sistem

3. Fase Perancangan Sistem secara Umum

4. Fase Evaluasi dan Seleksi Sistem

5. Fase Perancangan Sistem secara Detail

6. Fase Implementasi Sistem dan Pemeliharaan Sistem

Adapun Kelebihan dari model SDLC, yaitu mudah diaplikasikan dan memberikan template 
tentang metode analisis, desain, pengkodean, pengujian, dan pemeliharaan aplikasi.

\subsubsection{Analisis Sistem yang Berjalan}

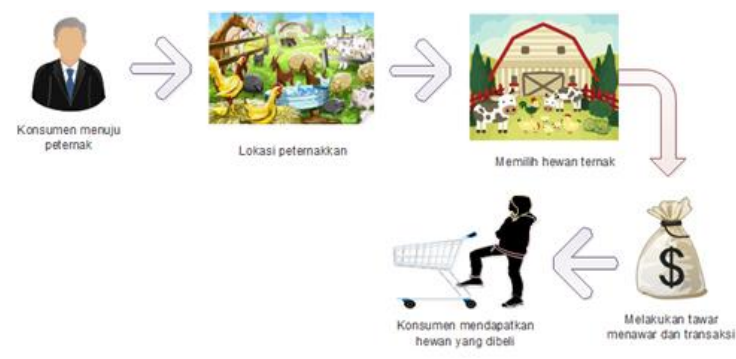

Gambar 1. Analisis sistem yang berjalan proses jualbeli secara tradisional atau tanpa terapan teknologi

Pada Sistem yang berjalan proses penjualan masih bersifat tradisional, seperti yang ditujukkan pada gambar 1 konsumen mendatangi lokasi peternakan, melihat dan memilih hewan yang akan dibeli. Setelah itu terjadi proses tawar menawar, dan langsung melakukan transaksi pembayaran. Kemudian konsumen membawa pulang hewan yang telah dibeli.

\subsubsection{Sistem yang Diusulkan}

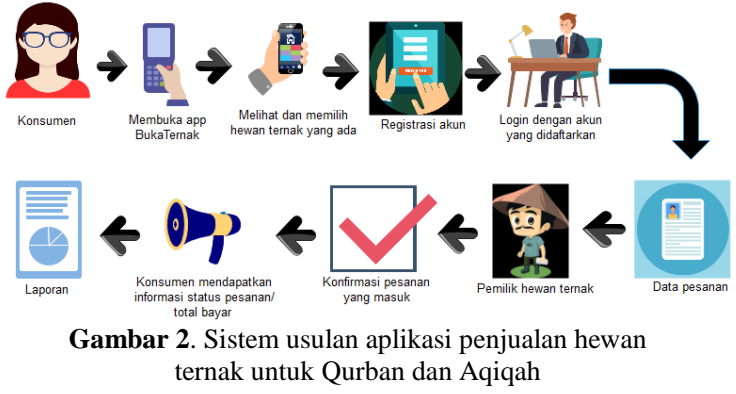

Seperti ditujukkan Gambar 2 Garis besar dari alur rancangan sistem aplikasi penjualan ternak, yang penulis usulkan dapat dideskripsikan sebagai berikut:

1. Konsumen sebagai pembeli hewan.

2. Konsumen yang ingin membeli hewan, membuka aplikasi Buka Ternak.

3. Kemudian konsumen melihat dan memilih hewan ternak yang ada di aplikasi.

4. Sebelum melakukan pemesanan, konsumen melakukan login ke aplikasi buka ternak.

5. Konsumen yang sudah mempunyai akun dapat melakukan login keaplikasi buka ternak. Konsumen yang belum mempunyai akun, maka harus melakuakan registrasi terlebih dahulu.

6. Setelah itu konsumen dapat melakukan pengimputan data pesanan yang akan dibeli.

7. Peternak adalah admin dari setiap hewan yang di promosikan dalam aplikasi.
8. Selanjutnya peternak mengkonfirmasi pesanan yang masuk kepadanya, kemudian peternak dan pembeli dapat melakukan chatting mengenai pemesanan yang dilakukan.

9. Kemudian konsumen mendapatkan informasi status pesanan dan total bayaran dari peternak.

10. Penjual dapat melihat informasi status pembayaran dan laporan hasil penjualan.

\subsubsection{Perancangan Sistem}

\subsection{Use Case}

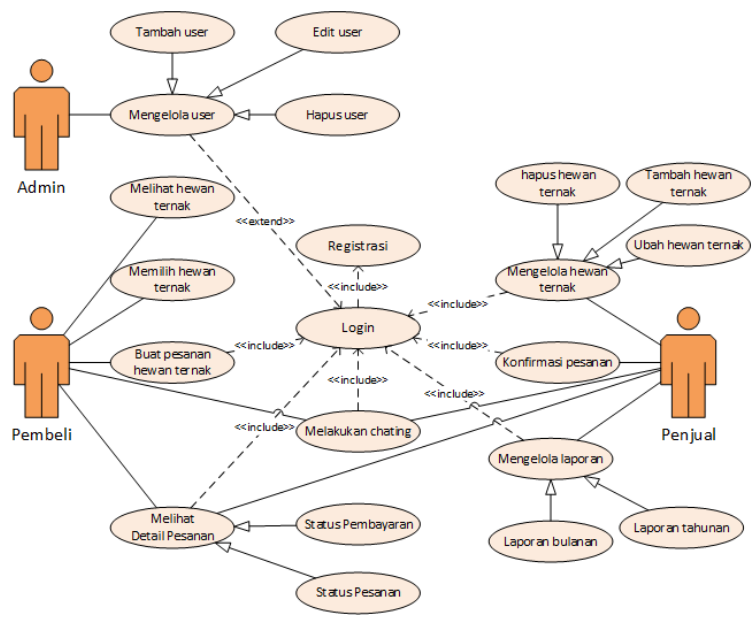

Gambar 3. Use case diagram perancangan aplikasi penjualan hewan ternak untuk Qurban dan Aqiqah

Dalam penyusunan suatu program diperlukan suatu model data yang berbentuk diagram yang dapat menjelaskan suatu alur system yang akan dibangun. Dalam penelitian ini penulis menggunakan metode UML yang dalam metode ini penulis menerapkan diagram use case (Peranginangin, 2006).

\subsection{Activity Diagram}

Activity Diagram, menggambarkan aliran kerja (workflow) atau aktivitas dari sebuah sistem atau proses bisnis atau menu yang ada pada perangkat lunak. Penggambaran activity diagram memiliki kemiripan dengan flowchart diagram (AlBahra, 2005). 


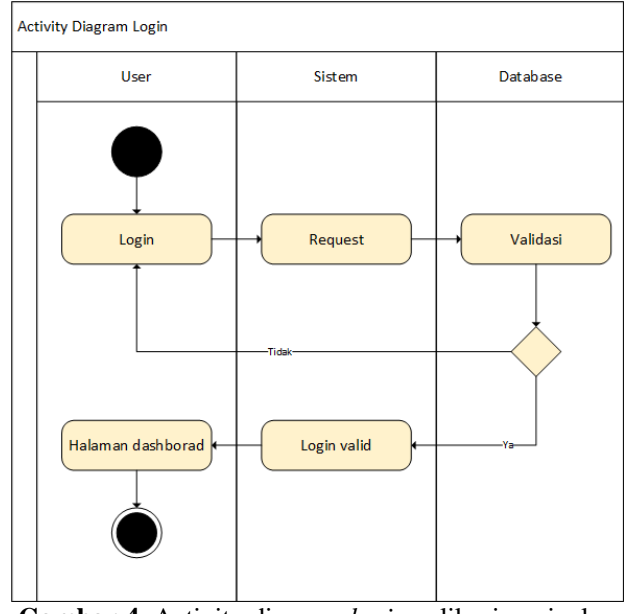

Gambar 4. Activity diagram login aplikasi penjualan hewan ternak untuk Qurban dan Aqiqah

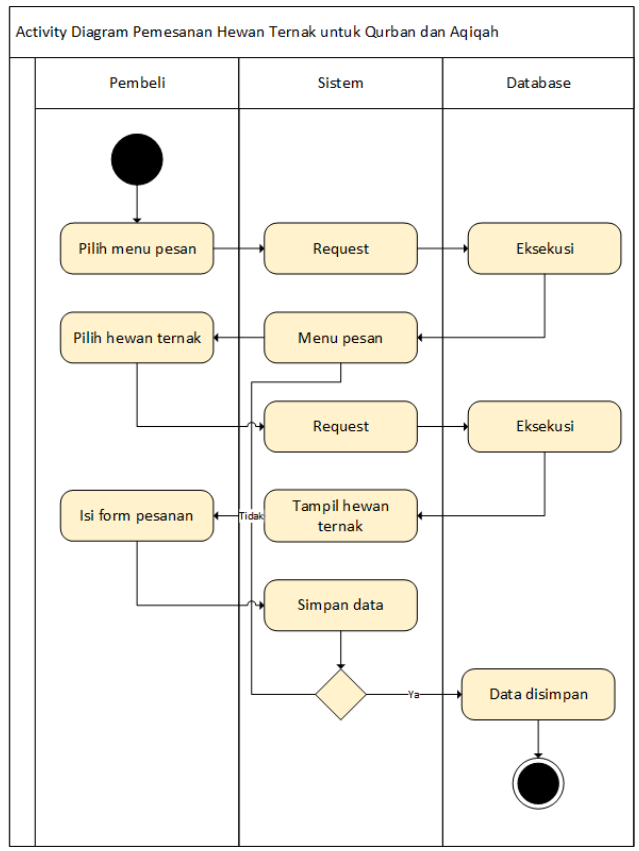

Gambar 5. Activity diagram pemesanan aplikasi penjualan hewan ternak untuk Qurban dan Aqiqah

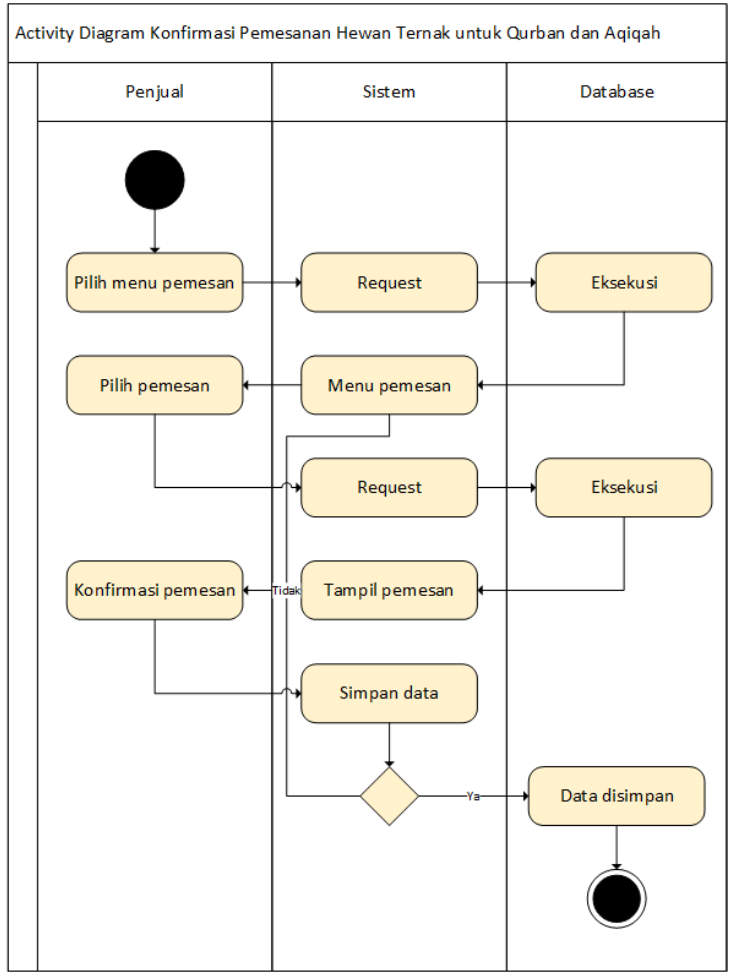

Gambar 6. Activity diagram konfirmasi pemesanan aplikasi penjualan hewan ternak untuk Qurban dan Aqiqah

\subsection{Class Diagram}

Class diagram menggambarkan struktur dan hubungan antar objek-objek yang ada pada system. Struktur ini meliputi atribut-atribut dan metodemetode yang ada pada masing-masing class.

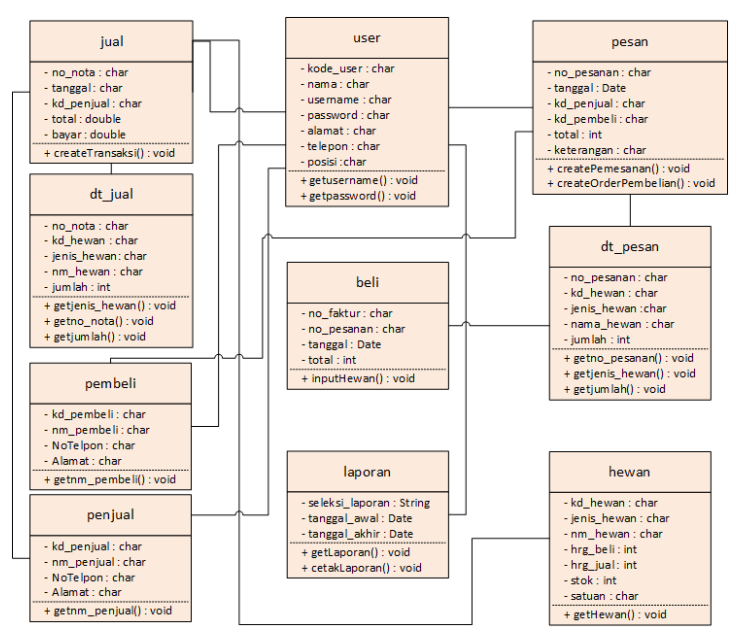

Gambar 7. Class diagram perancangan aplikasi penjualan hewan ternak untuk Qurban dan Aqiqah

\subsection{Analisis Program}

\subsubsection{Menu Utama}

Menu utama pada aplikasi ini menampilkan bagian menu dimana pada setiap menu yang 
tersedia pengguna dapat melihat daftar ternak, memesan ternak dan melihat profil.

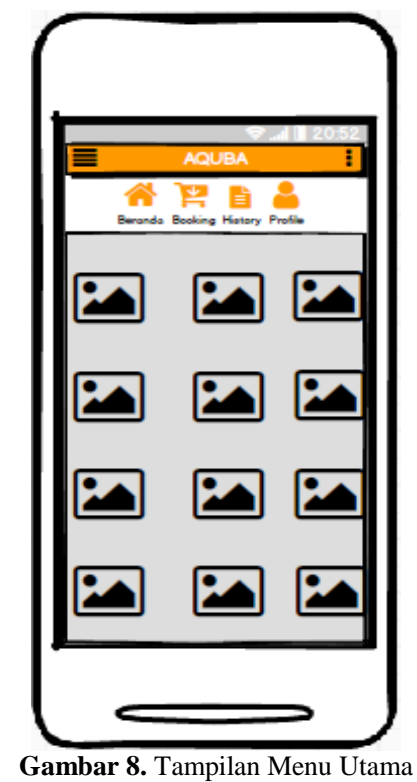

\subsubsection{Login}

Tampilan gambar 9 merupakan tampilan halaman login dari sitem yang akan dibangun. Dalam halaman login pengguna diminta memasukkan username dan password untuk bisa masuk ke dalam aplikasi. Apabila pengguna belum memiliki akun, pengguna dapat melakukan registrasi dan mengisi form registrasi untuk membuat akun pengguna.

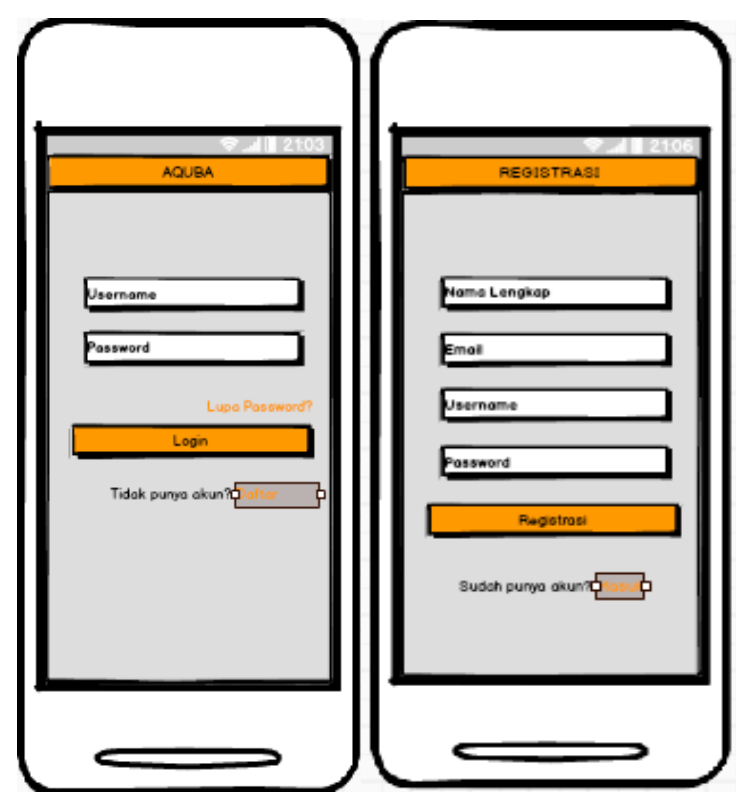

Gambar 9. Tampilan Login Dan Registrasi

\subsubsection{Daftar Ternak}

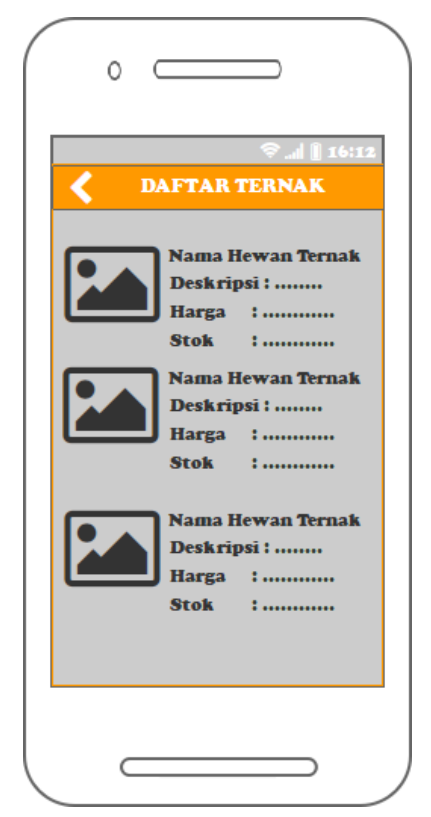

Gambar 10. Tampilan Daftar Ternak

Seperti ditunjukkan gambar 10 menampilkan daftar ternak yang dijual dalam aplikasi beserta rincian dari masing-masing hewan yang dijual.

\subsubsection{Menu Search}

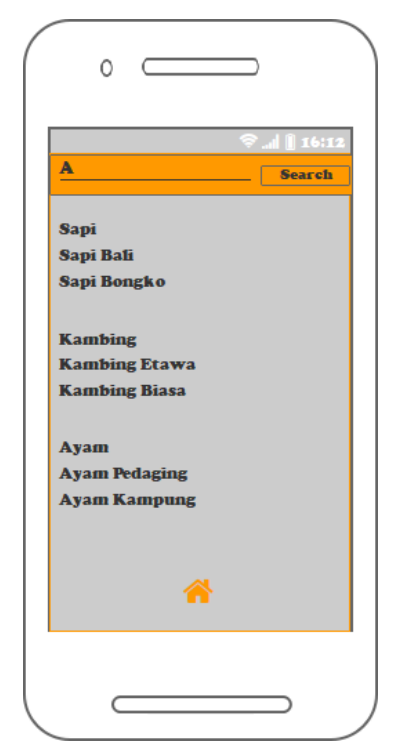

Gambar 11. Tampilan Menu Search

Dalam proses pencarian hewan, disini akan di tampilkan hasil pencarian yang sesuai dengan nama hewan yang akan dicari, seperti ditunjukkan Gambar 11. 


\subsubsection{Menu Penginputan Pesanan Dan Detail} Hewan

Pembeli akan masuk ke menu aplikasi dan melihat daftar hewan ternak yang tersedia dalam aplikasi, memilih salah satu jenis hewan yang akan dibeli, setelah itu akan ditampilkan detail hewan yang akan dipesan.
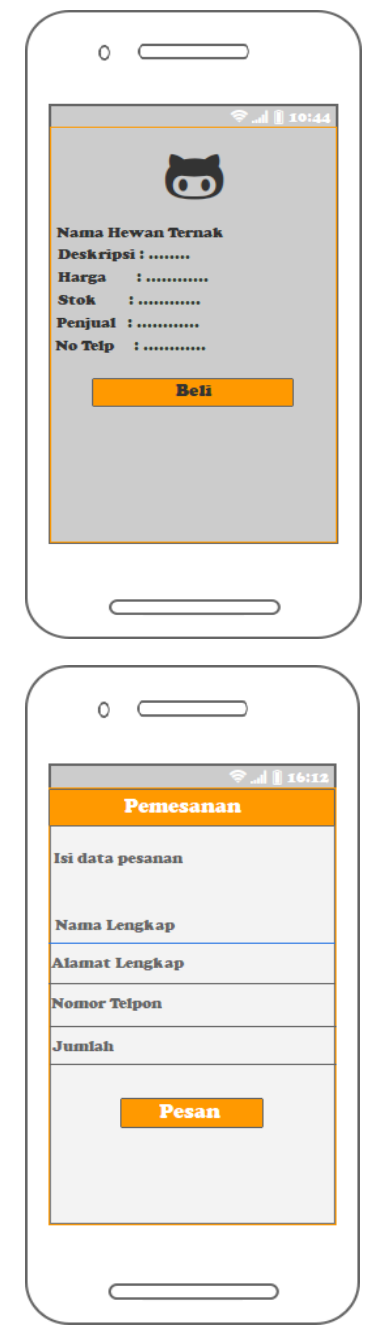

Gambar 12. tampilan menu pengimputan pesanan dan detail hewan

\subsection{Implementasi}

Implementasi adalah uji coba yang dibuat dengan menganalisa system secara rinci. Pada tahap ini dapat dilihat bagaimana system beroperasi. Tahap ini bertujuan untuk mengkonfirmasi perancangan sistem, sehingga dapat memberikan masukan dalam pengembangan sistem.

Adapun user interface pada aplikasi terdapat 3 tampilan untuk 3 role user yang berbeda, user pada aplikasi ini terdiri dari Admin, Konsumen dan Penjual. User interface aplikasi untuk admin dan penjual yaitu web service sedangkan konsumen melalui android.

\subsubsection{User Interface Login Web Service Admin dan Pejual}

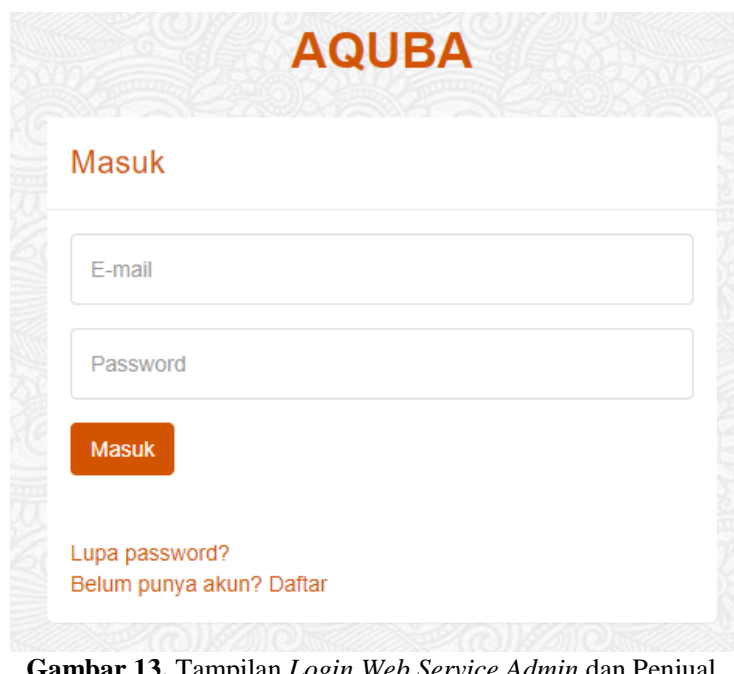

Sebelum masuk pada halaman website, admin dan penjual harus melakukan login pada aplikasi penjualan hewan qurban dan aqiqah.

\subsubsection{User Interface Dashboard Web Service} Admin

Setelah admin melakukan login, akan ditampilkan halaman dashboard yang berisi daftar pengguna aplikasi.

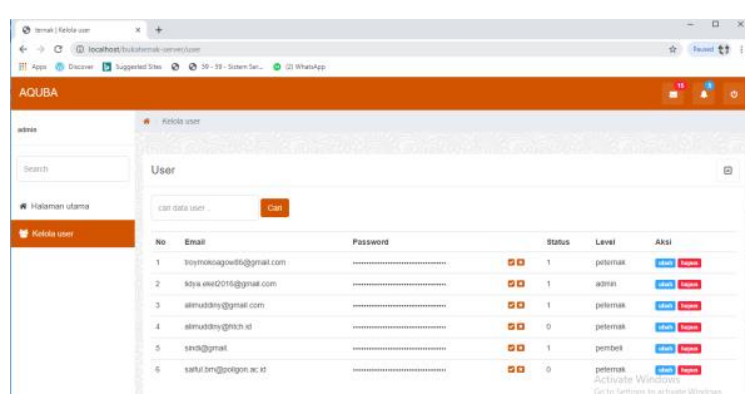

Gambar 14. Tampilan Dashborad Web Service Admin

\subsubsection{User Interface Dashboard Web Service Penjual}

Setelah penjual melakukan login, akan ditampilkan halaman dashboard yang berisi tentang detail ternak yang akan di jual, transaksi dan menu untuk menambah hewan yang di jual.

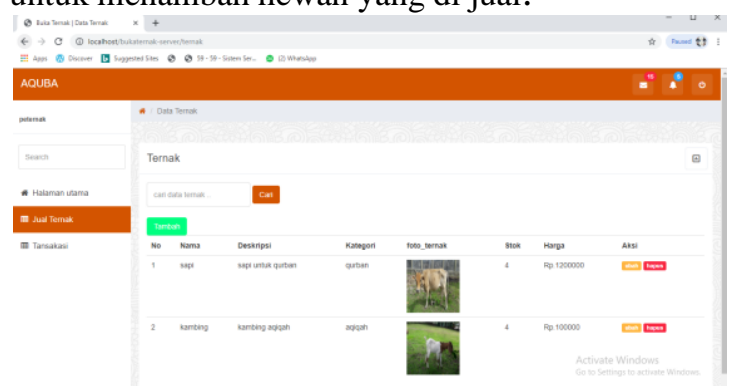

Gambar 15. Tampilan Dashborad Web Service Penjual 


\subsubsection{User Interface Login Konsumen}

Konsumen melakukan login terlebih dahulu dengan menggunakan email dan password yang telah di daftarkan sebelumnya.

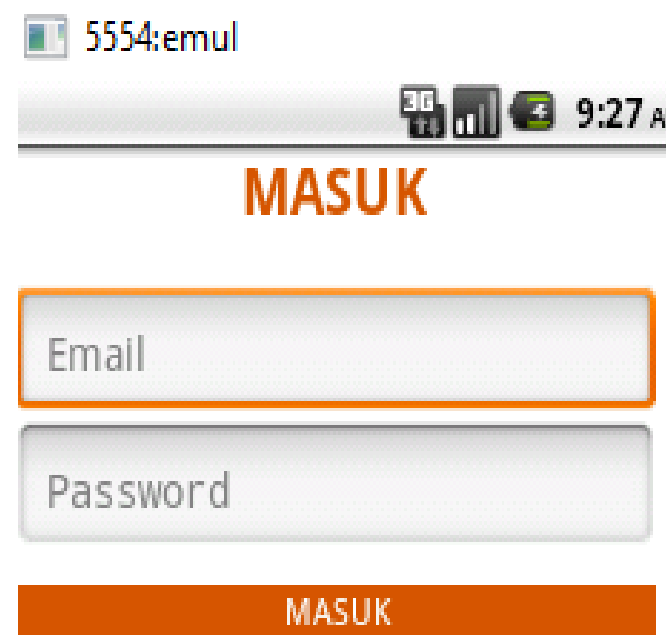

Belum punya akun? Daftar

Gambar 16. Tampilan login di Aplikasi Android

Setelah konsumen berhasil melakukan login, akan ditampilan informasi login berhasil.

5554:emul

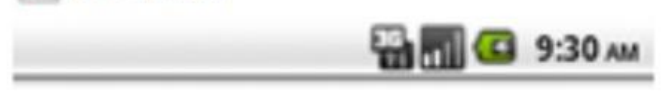

Selamat Datang troy

\section{Logout}

\section{Home Kategori Akan}

Gambar 17. Tampilan informasi ketika Login berhasil

\subsubsection{User Interface Home Konsumen}

Konsumen yang telah berhasil login dapat melihat dan melakukan pembelian pada aplikasi. Halaman ini akan menampilkan daftar ternak yang dijual. 5554:emul
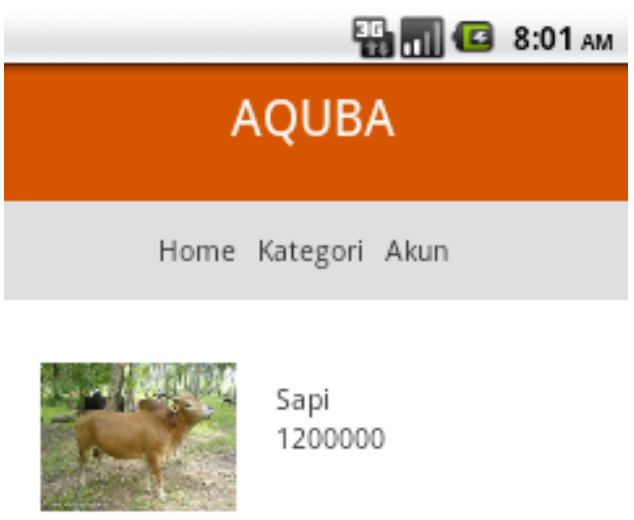

\section{Sapi}

1200000

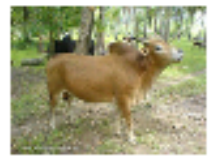

Kambing

100000

Gambar 18. Tampilan home konsumen

\subsubsection{User Interface Detail Ternak Konsumen}

Setelah konsumen telah memilih hewan yang dibeli, akan ditampilkan halaman detail dari hewan yang dipilih.

[1] 5554:emul

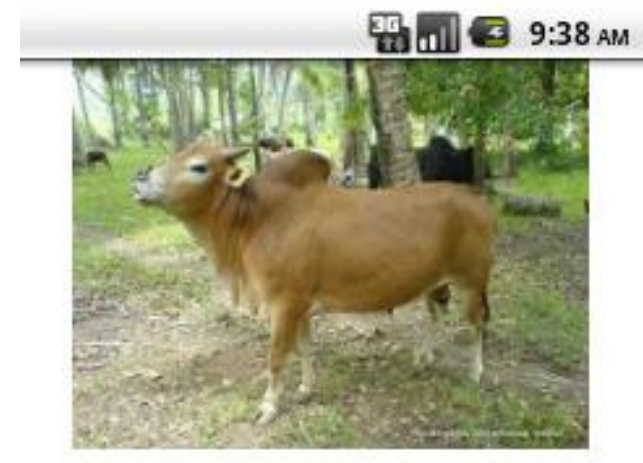

$$
\begin{aligned}
& \text { Nama: } \quad \text { Sapi } \\
& \text { Harga: } \quad 1200000 \\
& \text { deskripsi: Sapi Untuk Qurban } \\
& \text { kategori: }
\end{aligned}
$$

\section{Beli}

Gambar 19. Tampilan Detail Ternak

\subsubsection{User Interface Informasi Pembayaran}

Halaman ini akan memberikan informasi pembayaran dengan total harga ternak yang akan dibayar. 
5554:emul

\begin{tabular}{ll} 
Transaksi \\
\hline Nama Ternak: Sapi \\
Harga: & 1200000 \\
Stok: & 3 \\
Kategori: & Qurban
\end{tabular}

푼미의 9:41 Ам

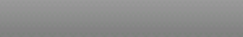

Kategori: Qurban

\section{Beli}

Gambar 20. Tampilan Informasi Pembayaran

Setelah melakukan berhasil melakukan pembelian, konsumen akan mendapatkan informasi bahwa ternak yang akan dibeli berhasil.

[1] 5554:emul

Konfirmasi

Selamat! Ternak yang kamu beli berhasil dibuat. Silahkan menunggu konfirmasi dari peternak..

Cara melakukan pembayaran yaitu dengan menggunakan Cash on Delivery!

Home

Gambar 20. Tampilan konfirmasi pembelian

\subsection{Hasil Observasi terhadap Manfaat Aplikasi}

Berdasarkan kuisioner yang di telah disebar, penulis mendapat 98 responden yang mengisi data, dari hasil tersebut, penulis mengolah data yang ada sebagai berikut:

\section{Jenis Kelamin}

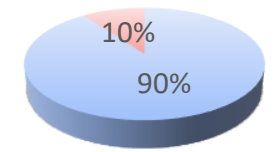

- Laki-laki @ Perempuan

Gambar 21. Identifikasi berdasarkan gender

\section{Usia}

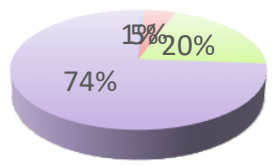

$\square 17-20 \quad 21-24 \quad 25-29 \square>40$

Gambar 22. Identifikasi berdasarkan umur

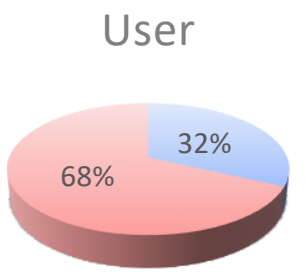

- Penjual Pembeli

Gambar 23. Identifikasi berdasarkan pengguna

\section{Kepuasan User}

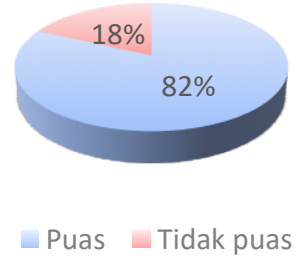

Gambar 24. Identifikasi berdasarkan tingat kepuasan

Dari hasil research dan dengan menggunakan data yang didapat dari responden, didapat bahwa tingkat kepuasan terhadap aplikasi penjualan hewan ternak untuk qurban dan aqiqah sebesar $82 \%$, sedangkan sisanya $18 \%$ pengguna tidak puas. Hal ini menunjukkan bahwa aplikasi penjualan hewan ternak untuk qurban dan aqiqah sangat bermanfaat dalam proses jual beli hewan untuk qurban dan aqiqah. 


\section{KESIMPULAN}

Berdasarkan hasil observasi, diksusi, evaluasi dan implementasi uji aplikasi yang telah dilakukan, maka dapat disimpulkan bahwa aplikasi penjualan hewan ternak untuk qurban dan aqiqah ini dapat membantu konsumen dalam melakukan pembelian hewan qurban dan aqiqah, serta meningkatkan pendapatan penjual hewan ternak.

\section{DAFTAR PUSTAKA}

Abdullah, M. (2016). Qurban: Wujud Kedekatan Seorang Hamba Dengan Tuhannya. Jurnal Pendidikan Agama Islam - Ta'lim, 109-116.

Al-Bahra. (2005). Analisis dan Desain Activity Diagram. Yogyakarta: Graha Ilmu.

AL-KUSYAIRI, M. K. (2015). Nilai-Nilai Pendidikan dalam Hadits Ibadah Aqiqah. Jurnal Al-hikmah, 152-162.

Kenneth E. Kendall, J. E. (2003). Analisis dan Perancangan Sistem Edisi Ke 5 Jilid 2. Jakarta: PT. Indeks Kelompok Gramedia.

Ladjamudin. (2005). Analisis dan Desain Sistem Informasi. Yogyakarta: Graha Ilmu.

Oktaviani, I., \& Suryadi, R. L. (2017). Sistem Informasi Penjualan Kambing dan Pemesanan Aqiqah. Jurnal INFORMA Politeknik Indonusa Surakarta, 23-29.

Peranginangin, K. (2006). Aplikasi Android dengan Use case. Yogyakarta.

Wati, A. S. (2012). Strategi Pengembangan Usaha Peternakan Sapi Potong di Kabupaten Pesisir Selatan. Jurnal Peternakan Indonesia, 249262. 